\title{
The Pearl River Declaration: a timely call for enhancing health security through fostering a regional one health collaboration in the Asia-Pacific
}

Noore Alam ${ }^{1,2}$, Cordia Chu', Qianlin Li ${ }^{3}$, Allison Crook ${ }^{4}$, Maxine Whittaker ${ }^{5}$, Tjandra Aditama ${ }^{6}$, Elena Schak ${ }^{1}$, Dicky Budiman ${ }^{1}$, Bonnie Barber ${ }^{1}$ and Jiahai $\mathrm{Lu}^{3^{*}}$

\begin{abstract}
The Second International Symposium on One Health Research (ISOHR) was held in Guangzhou city, China on 23-24 November 2019. A transdisciplinary collaborative approach, One Health $(\mathrm{OH})$, was the central theme of the symposium which brought together more than 260 experts, scholars and emerging researchers from human health, veterinary health, food safety, environmental health and related disciplines and sectors. More than 50 organizations including World Health Organization, Centers for Disease Control (USA), and Queensland Government (Australia) participated in the symposium. Scholars, experts and emerging researchers, policy-makers and practitioners in their respective fields delivered over 50 presentations at the symposium, highlighting the collective vulnerability to some of the emerging health challenges the region was combating. These included emerging infectious diseases, antimicrobial resistance, climate change, food safety and the growing burden of non-communicable diseases. The Pearl River Declaration, emanated from the symposium, called for establishing a One Health Cooperation Network in the Southeast Asia-Pacific region with a vision to strengthen regional health security through sharing each other's knowledge and experience, and making investments in workforce development, scientific innovations such as vaccine research and development, sharing epidemic intelligence, risk identification, risk communication and appropriate response measures against emerging health threats.
\end{abstract}

Keywords: Health security, Emerging infectious disease, Antimicrobial resistance, One health, Transdisciplinary collaboration, China

\section{Introduction}

Emerging infectious diseases, antimicrobial resistance, climate change, food safety and security, and the growing burden of non-communicable diseases were identified as some of the most pressing challenges to global health security at the Second International Symposium on One Health Research (ISOHR) held in Guangzhou,

\footnotetext{
* Correspondence: lujiahai@mail.sysu.edu.cn

${ }^{3}$ One Health Research Centre, School of Public Health, Sun Yat-sen University, Guangzhou, Guangdong Province, China

Full list of author information is available at the end of the article
}

China on 23-24 November 2019. The symposium was jointly organized by Sun Yat-sen University (China), Griffith University (Australia), South China Agricultural University (China) and Guangzhou Medical University (China). A transdisciplinary collaborative approach, known as One Health, was identified as a key opportunity to promote human, animal and environmental health within and between countries around the world [1]. The symposium sought to facilitate a shared understanding of transdisciplinary synergies and the need for a multi-

(c) The Author(s). 2020 Open Access This article is licensed under a Creative Commons Attribution 4.0 International License, which permits use, sharing, adaptation, distribution and reproduction in any medium or format, as long as you give appropriate credit to the original author(s) and the source, provide a link to the Creative Commons licence, and indicate if changes were made. The images or other third party material in this article are included in the article's Creative Commons licence, unless indicated otherwise in a credit line to the material. If material is not included in the article's Creative Commons licence and your intended use is not permitted by statutory regulation or exceeds the permitted use, you will need to obtain permission directly from the copyright holder. To view a copy of this licence, visit http://creativecommons.org/licenses/by/4.0/ The Creative Commons Public Domain Dedication waiver (http://creativecommons.org/publicdomain/zero/1.0/) applies to the data made available in this article, unless otherwise stated in a credit line to the data. 
sectoral collaboration in research and practice to tackle the growing threats to global health security.

The ISOHR brought together more than 260 experts, scholars and emerging researchers from China and around the world in as diverse areas as public health, clinical medicine, veterinary medicine, laboratory science, food safety, environmental health, agricultural science, military medicine, health systems and policies. More than 50 organizations including multiple Chinese Government departments and research institutions, and representatives from World Health Organization, Centers for Disease Control (USA), and Queensland Government (Australia) participated in the symposium.

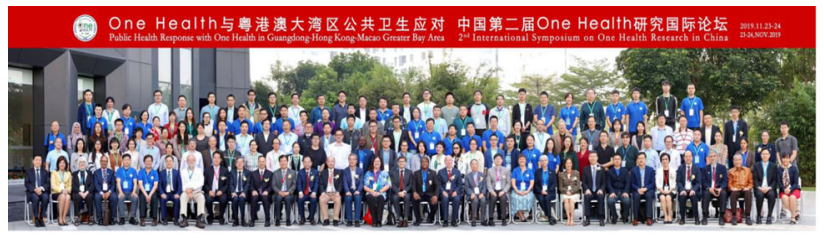

Delegates at the Second International Symposium on One Health Research, Guangzhou China. Photo source: Sun Yat-sen University.

Over the past two centuries the world has witnessed spectacular innovations and successes in public health and medical science. The most notable among those were the invention of vaccines (1796 AD) and antibiotics (1928), the eradication of small pox (1979) and the introduction of a simple, low-cost oral rehydration therapy (sugar-salt-clean water solution) for treatment of dehydration caused by diarrhea. Collectively, these innovations have saved tens of millions of lives [2-4]. These achievements may have provided a sense of complacency to some for wining over epidemic diseases. Ironically, this complacency was challenged by the emergence of some of the deadly diseases such as human immunodeficiency virus (HIV) in the 1980s, severe acute respiratory syndrome (SARS) in 2002 [5], and lately, the 2019 coronavirus disease (COVID-19).

The novelty of the virus, the nature and speed of the interspecies and cross-border transmission of COVID-19 prompted World Health Organization to declare it a 'Public health emergency of international concern' [6], whereas SARS prompted the overhaul of the global health governance mechanisms resulting in the International Health Regulations 2005 [7].

\section{Infectious diseases}

The ISOHR observed with a great concern that over the past five decades, the world has witnessed the emergence of about 40 new diseases including Legionnaires' disease, HIV/AIDS, hepatitis C, mad-cow disease, SARS, Middle East Respiratory Syndrome (MERS), Nipah and Ebola virus diseases. Twenty of these diseases were found in China alone [8]. Many of these new diseases along with the existing climate-sensitive vector-borne diseases such as dengue, Zika and West Nile virus, remain ongoing threats to health security worldwide [9]. Many emerging diseases, after a period of absence or being controlled, re-emerge as epidemic with devastating impacts. For example, dengue in Bangladesh in 2019 [10], measles in the Pacific since 2017 [11] and polio in the Philippines in 2019 [12]. Malaria, multidrug-resistant tuberculosis, HIV/AIDS, neglected tropical diseases and viral hepatitis affect billions of people worldwide, and are responsible for more than 4 million deaths annually, where the vast majority are in low- and middle-income countries (LMICs) [13]. The ISOHR noted that approximately 75\% of emerging diseases originate in animals (zoonoses) with greater frequency of outbreaks and significantly higher burden in LMICs than high-income countries [14-17].

The ISOHR acknowledged the role of economic globalization in the twenty-first century and the associated growth in tourism and trade. These and other developments have significantly increased the mobility of populations and trade in goods worldwide and increased the risk of infectious disease spread across regions and countries. In some areas this has resulted in a continuing epidemic and pandemic threat. The impact of global climate change, agricultural intensification, rapid economic growth combined with population growth and urbanization, further complicate public health challenges globally and more specifically in LMICs [18]. Today, more than half of the world's 7.7 billion population live in the South Asia and South-East Asia-a region which includes China, India, Indonesia, Bangladesh, Pakistan and Vietnam [19]. This densely populated region hosts some of the fastest growing economies in the world, and faces a wide range of challenges including climate change, food safety and emerging infectious disease threats. Many of these countries are often dubbed as 'emerging disease hotspots'. [20]

In the recent past, the region has experienced some of the deadliest epidemics resulting in formidable losses not only to health but also impacting heavily on their economies with substantial sociological and political repercussions [20]. For example, after the 2002-03 SARS pandemic [21], which caused enormous losses to health and economies of over 30 countries, the highly pathogenic avian influenza (H5N1) has become endemic in parts of China and other countries in the region including Bangladesh, Indonesia, and Vietnam, and in parts of Africa [22]. The combination of avian and human strains in a favorable environment can result in a sustained spread from birds to human, and then human to human with a potential for a pandemic causing large-scale illnesses and deaths worldwide. There is an overwhelming body of evidence that infectious disease occurs at human-animal-environment interface and that their 
transmissions and the magnitude of impacts are influenced by many factors including behavioral, social, environmental, and cultural [20]. These recognitions have been the catalyst to call for a broad-based, holistic approach, known as One Health $(\mathrm{OH})$, which is defined as, "The collaborative effort of multiple health science professions, together with their related disciplines and institutions - working locally, nationally, and globally to attain optimal health for people, domestic animals, wildlife, plants, and our environment" [23].

Countries increasingly recognize the value of working collaboratively and sharing knowledge, expertise and resources for the protection of their own country and to address the collective vulnerability in today's globalized world. This recognition is evidenced by the Australian Government's regional health security initiative known as 'Indo-Pacific Centre for Health Security' established in 2017 [24]. The initiative is focused on a holistic, transdisciplinary and multisectoral approach, known as "One Health" $(\mathrm{OH})$, to strengthen the health security capacity across the Indo-Pacific region [24].

\section{Antimicrobial resistance}

The ISOHR noted with concern that the growing antimicrobial resistance (AMR) was a significant threat to the core of modern medicine as it seriously hampers the efficacy and sustainability of an effective public health response to infectious diseases. The complex root of the problem and the process of widespread, systematic misuse of antibiotics in human and animal medicine, and in food production, demands systematic and coordinated action involving multiple sectors, and disciplines beyond health [25]. The unregulated and often uncontrolled use of antibiotics in human medicine as well as the overuse of non-therapeutic antibiotics in animals for food production compromises the health of the public and challenges health systems globally. The intersection between veterinary sanitary, food safety and public health is a highly regulated area, particularly across the European Union which has a legislative basis for action against AMR [26]. A regional collaboration such as the proposed One Health Cooperation Network in the Southeast Asia and the Pacific region, as pronounced at the ISOHR's call, could play a pivotal role in creating a similar legislative environment in the region as well as enhancing a holistic, transdisciplinary response to AMR.

\section{Chronic diseases}

Infectious diseases and AMR are not the only causes of concern for the global health security. Similarly, the scope of $\mathrm{OH}$ is not limited to infectious disease only. The growing burden of chronic disease, the double burden of malnutrition which is defined as the coexistence of overnutrition (overweight and obesity) and undernutrition (stunting and wasting) [27], climate change and its impacts are some of the emerging threats all countries are facing in one way or another.

\section{The one health approach}

Infectious disease transmission occurs at the humananimal-environment interface. The magnitude of the impact of disease and its transmission is influenced by many factors including human behavior, and society, the environment, and the culture of the community. Thus, a broad-based, holistic approach, known as One Health $(\mathrm{OH})$, has received prominence in recent years. Countries increasingly recognize the collective vulnerability to emerging health security threats such as epidemics and pandemics and seek to forge joint effort for mutual benefit. One example of such collaboration effort is the Australian Government's regional health security initiative, the 'Indo-Pacific Centre for Health Security'. [24] Established in 2017, the initiative focuses on a holistic, transdisciplinary approach, "One Health" $(\mathrm{OH})$, to strengthen the health security capacity across the Indo-Pacific region. The ISOHR called for a $\mathrm{OH}$ approach to collaborative research and practice which would provide opportunities for better understanding of emerging health risks, and avenues for collaborative and coordinated action for prevention through risk identification, risk communication, sharing epidemic intelligence and appropriate control measures. While the focus of $\mathrm{OH}$ has been traditionally on infectious zoonotic diseases, its scope and application can be as diverse as agricultural production and land use to climate change, biodiversity and environmental health to food safety--anything that transects the human, animal and environments, thus opportunities for maximizing the benefits of $\mathrm{OH}$ approach [28].

\section{Strengthening the one health approach in the Asia-Pacific region}

Looking through the lens of etiology, infectious diseases are not only caused by bacteria, viruses and parasites. They are also influenced or shaped by social, economic, political, legal and cultural conditions. Thus, the breadth of emerging health issues and the application of $\mathrm{OH}$ to address those will go much farther than the traditional health outlook.

In line with its fast-paced economic development, China remains focused on combating emerging health threats including emerging infectious diseases such as SARS and the coronavirus disease (COVID-19), and controlling the spread of antimicrobial resistance $[8,29]$. Having learnt the lessons from SARS, including the application of a holistic $\mathrm{OH}$ approach, China was able to successfully counter some of the potentially pandemic diseases such as H5N1, H1N1 and H7N9 [8]. By making 
sustained, incremental investments in health, China is pioneering through its efforts in promoting the $\mathrm{OH}$ approach to research and practice to address emerging health challenges of the twenty-first century $[28,30]$. In today's globalized and increasingly complex world, emerging public health issues that transect international borders often become complicated issues and require international law [31]. The need for effective health diplomacy [32], both state-and non-state-based arrangements for multidisciplinary collaborative research, exchange of knowledge and information between sectors and disciplines within and among countries has thus never been greater [33].

In line with this acknowledgement, the Pearl River Declaration [28] (Table 1) called for establishing a One Health Collaboration Network encompassing countries across the greater South-Southeast Asia and the Pacific region with a vision to contribute to building a shared future for all of the world. Although the concept of $\mathrm{OH}$ and the value of its essence, collaboration, is generally accepted by relevant inter-related sectors and disciplines, its application in dealing with emerging health issues has often been described as limited, particularly in resourcelimited settings [34]. To overcome those limitations, focused actions in four areas; legislation, communication, education and investment were recommended at the first International Symposium of $\mathrm{OH}$ Research in Guangzhou, China in 2014 [30]. Half a decade later, the need for continuous actions on those areas were resounded at the second ISOHR in 2019 [28].

The process of initiating such a regional collaboration by Griffith University, a co-convener of the ISOHR, began as early as 2016 with the establishment of the Global Research Consortium on Risk Communication, Emergency Management and Adaptation to Climate Change for Health (REACCH). This was undertaken in partnership with 15 institutions including government departments across the region. REACCH members have contributed to joint research, policy advocacy and capacity-building to improve health systems and address collective vulnerability to emerging health threats.

The establishment of a cross-disciplinary Research and Policy Advocacy Hub for Global Health Security at Griffith University, Australia in 2019 further supports this overall regional objective. The Hub hosts two broad networks:

(i.) The One Health Research Network, established in 2016--a collaboration with One Health networks in China and Indonesia, focusing on diseases that occurs at human-animal-environment interface.

(ii.) The country programs network for Bangladesh, China, Indonesia, Mongolia, the Philippines and Vietnam, consisting of many institutional members
Table 1 The Pearl River Declaration, Guangzhou, China, 24 November 2019

Five years ago, we gathered together in Guangzhou to discuss the way forward in bringing about One Health in China. Over the next 5 years, we held the first China One Health Symposium where we signed the Yuexiu Mountain Declaration, setting up the first One Health Research Center, and assembling the "China One Health League", marking a substantial step forward for the One Health research in China. Since then, we have made great progress, with substantial efforts to accelerate the construction of an interdisciplinary, multisectoral, cross regional international collaborative platform for One Health, helping to move One Health from concept to practice. Although we have made great strides, much remains to be done.

In this second decade of the twenty-first century, the world is undergoing complex changes that pose enormous challenges to human health worldwide. This is marked by the cross-species transmission of pathogens, intensive agriculture, the overuse of antibiotics, and environmental and food pollution. It has been reported that over $70 \%$ of emerging infectious diseases are zoonoses, while multi-drug and super-drug resistant bacterial pathogens constantly emerge, and there are increasingly frequent food-borne diseases and food safety incidents. As China seeks to contribute to building a shared future for all of the world through its Belt and Road initiative, by supporting the construction of Greater Bay Area, and by enhancing economic globalization, it faces complex challenges from public health, veterinary health and environmental health, as well as food safety. These problems cannot be solved by single department or discipline. Thus. we must tackle the world's health issues through the One Health approach.

China's One Health action has entered a new stage. We must now foster good regional leadership, and focus on expanding, developing and strengthening the One Health Cooperation Network in Southeast Asia and the Pacific. We can continue to improve this platform and make it more efficient by strengthening our ties within this region. This will enhance our ability to carry out comprehensive, cooperative research. China and Southeast Asia should coordinate their efforts to build a shared future, by establishing ongoing One Health training courses, jointly cultivating young talent, creating efficient information exchange networks, and sharing information and resources, so that together we can face and meet the world's health challenges.

Mountains and seas are no obstacle to people with the same aspirations. The development of China's One Health benefits from full openness and active communication. In the future, communication and cooperation should be carried out at a higher level, with a broader scope and in a wider range of fields. We will firmly and steadily promote One Health to achieve concrete outcomes. With water-like persistence and kindness, we will encourage people's trust in and support for One Health. We will learn from the international One Health movement and take its momentum forth, sharing its ideas to benefit our neighbors, and the world.

We have only one planet, and we live together in one world. Let us work together to create ONE WORLD, ONE HEALTH.

from these countries guided by a Memorandum of Understanding of each with Griffith University, having been gradually expanded since 2006. These collaborations focus on health system policies and operational capacity building in the region, as well as emerging health challenges including climate change adaptation, disaster risk reduction, zoonotic and vector-borne disease control.

Among many tangible outcomes achieved through the establishment and function of these networks has been the delivery of over 10 public health leadership programs 
that have successfully nurtured more than 120 Fellows across the region. Many of these Fellows have gone on to leadership of the COVID-19 pandemic response in their respective countries over recent months [35].

\section{Conclusion}

Addressing emerging health challenges is the collective responsibility of nations as they are collectively vulnerable in the globalized world. If health is for all, as it is often heard being said, then all should be working for health. The resounding message of the Pearl River Declaration was the need for greater commitment and collaboration among nations across the mountains and seas under the umbrella of $\mathrm{OH}$ for a future healthy global community. As important regional development partners in health in the Indo-Pacific region, countries such as Australia, China, Thailand, Singapore and international bodies such as Asian Development Bank and WHO can play a pivotal role in country-capacity building through sharing knowledge and experience, as well as making investments in workforce development, scientific innovations such as vaccine research and development. These can be better achieved through establishing a regional One Health Cooperation Network.

\section{Acknowledgements}

The authors acknowledge the valuable feedback provided to the manuscript by the following individuals: Ms. Margaret Bright, former Epidemiology Manager, Queensland Health, Australia. Prof. Vipat Kuruchittham, Executive Director, Southeast Asia One Health University Network, Thailand.

\section{Authors' contributions}

NA and CC conceived and planned the structure of the article. NA took the lead in writing the manuscript with $C C$ supervised the write up. QL, JL, AC, MW, TA, ES, DB and BB contributed with contents and provided critical feedback. CC and JL finalized the manuscript. The authors read and approved the final manuscript.

\section{Funding}

This work was supported by The National Science and Technology Major Project (Grant No. 2018ZX10101002) and Guangdong Provincial Science and Technology Project (Grant No. 2018B020241002).

\section{Availability of data and materials}

No primary data collection was involved in this article. All secondary data presented in this article have been appropriately referenced to their original sources.

\section{Ethics approval and consent to participate}

Not applicable.

\section{Consent for publication}

Not applicable.

\section{Competing interests}

All co-authors declare no competing interests.

\section{Author details}

${ }^{1}$ Centre for Environment and Population Health, Griffith University, Nathan, Australia. ${ }^{2}$ Queensland Health, Queensland Government, Brisbane, Australia. ${ }^{3}$ One Health Research Centre, School of Public Health, Sun Yat-sen University, Guangzhou, Guangdong Province, China. ${ }^{4}$ Department of Agriculture and Fisheries, Queensland Government, Brisbane, Australia. ${ }^{5}$ James Cook
University, Townsville, Australia. ${ }^{6}$ World Health Organization, New Delhi, South-East Asia Region, India.

Received: 15 April 2020 Accepted: 29 July 2020

Published online: 07 September 2020

\section{References}

1. One Health Commission. What is One Health? Available: https://www. onehealthcommission.org/en/why_one_health/what_is_one_health/ Accessed 7 Jan 2020.

2. Fontaine $O$, Garner $P$, Bhan MK. Oral rehydration therapy: the simple solution for saving lives. BMJ. 2007;334(suppl 1):s14. https://doi.org/10.1136/ bmj.39044.725949.94.

3. Ventola $\mathrm{CL}$. The antibiotic resistance crisis: part 1: causes and threats. PT. 2015:40(4):277-83

4. World Health Organization. The power of vaccines: still not fully utilized. Available: https://www.who.int/publications/10-year-review/vaccines/en/ Accessed 6 Feb 2020.

5. Centers for Disease Control and Prevention. CDC SARS response timeline. Available: https://www.cdc.gov/about/history/sars/timeline.htm Accessed 31 December 2019

6. World Health Organization. Statement on the second meeting of the International Health Regulations (2005) Emergency Committee regarding the outbreak of novel coronavirus (2019-nCov). Available: https://www.who. int/news-room/detail/30-01-2020-statement-on-the-second-meeting-of-theinternational-health-regulations-(2005)-emergency-committee-regardingthe-outbreak-of-novel-coronavirus-(2019-ncov) Accessed 31 Jan 2020.

7. World Health Organization. International Health Regulations 2005. WHO. Available: https://www.who.int/ihr/publications/9789241580496/en/ Accessed 20 Aug 2019.

8. Wu J, Liu L, Wang G, Lu J. One health in China. Infect Ecol Epidemiol. 2016; 6:33843. https://doi.org/10.3402/iee.v6.33843.

9. Campbell-Lendrum D, Manga L, Bagayoko M, Sommerfeld J. Climate change and vector-borne diseases: what are the implications for public health research and policy? Philos Trans R Soc Lond Ser B Biol Sci. 2015; 370(1665):20130552. https://doi.org/10.1098/rstb.2013.0552.

10. Mone FH, Hossain S, Hasan MT, Tajkia G, Ahmed F. Sustainable actions needed to mitigate dengue outbreak in Bangladesh. Lancet. 2019;19(11): P1166-7. https://doi.org/10.1016/S1473-3099(19)30541-9.

11. World Health Organization. Measles outbreaks in the Pacific. Available: https://www.who.int/westernpacific/emergencies/measles-outbreaks-in-thepacific Accessed 2 January 2020.

12. World Health Organization. Polio outbreak in the Philippines. Available: https://www.who.int/westernpacific/emergencies/polio-outbreak-in-thephilippines Accessed 2 January 2020.

13. World Health Organization. Communicable Diseases (CDS). Available: https://www.who.int/about/structure/organigram/htm/en/ Accessed 30 December 2019

14. Abdullah A, Wolfe R, Stoelwinder J, et al. The number of years lived with obesity and the risk of all-cause and cause-specific mortality. Int J Epidemiol. 2011;40:985-96. https://doi.org/10.1093/ije/dyr018.

15. Cleaveland S, Sharp J, Abela-Ridder B, et al. One health contributions towards more effective and equitable approaches to health in low- and middle-income countries. Philos Trans R Soc Lond Ser B Biol Sci. 2017; 372(1725):20160168. https://doi.org/10.1098/rstb.2016.0168.

16. Grace $D$, Mutua $F$, Ochungo $P$, et al. Mapping of poverty and likely zoonoses hotspots. ILRI, Kenya. Available: https://www.gov.uk/dfid-research-outputs/ mapping-of-poverty-and-likely-zoonoses-hotspots\#citation Accessed 31 Dec 2018

17. Jones K, Patel N, Levy M, Storeygard A, Balk D, Gittleman J. Global trends in emerging infectious diseases. Nature. 2008;451(7181):990-3.

18. Olson SH, Benedum CM, Mekaru SR, et al. Drivers of emerging infectious disease events as a framework for digital detection. Emerg Infect Dis. 2015; 21(8):1285-92. https://doi.org/10.3201/eid2108.141156.

19. World population review. 2019 world population by country. Available: http://worldpopulationreview.com/ Accessed 5 Dec 2019.

20. Coker RJ, Hunter BM, Rudge JW, Liverani M, Hanvoravongchai P. Emerging infectious diseases in Southeast Asia: regional challenges to control. Lancet. 2011;377(9765):599-609. https://doi.org/10.1016/s0140-6736(10)62004-1.

21. LeDuc J, Barry M. SARS, the first pandemic of the 21st century. Emerg Infect Dis. 2004;10(11):e26. https://doi.org/10.3201/eid1011.040797_02. 
22. Centers for Disease Control and Prevention. Highly pathogenic Asian avian influenza A (H5N1) virus. Available: https://www.cdc.gov/flu/avianflu/h5n1virus.htm Accessed 8 Jan 2020.

23. One Health Commission. One Health Commission homepage. Available: https://www.onehealthcommission.org/ Accessed 9 January 2019.

24. Department of Foreign Affairs and Trade. Indo-Pacific Centre for Health Security. Australian Government. Available: https://indopacifichealthsecurity. dfat.gov.au/ Accessed 28 December 2019.

25. World Health Organization. Antimicrobial resistance. Strategic and Technical Advisory Group (STAG) on antimicrobial resistance. WHO. Available: https:// www.who.int/antimicrobial-resistance/events/stag/en/ Accessed 3 Dec 2019.

26. Bondoc I. European Regulation in the Veterinary Sanitary and Food Safety Area, a Component of the European Policies on the Safety of Food Products and the Protection of Consumer Interests: A 2007 Retrospective. Part Two: Regulations. Universul Juridic 2016; Supplement: 16-9. Available: http://revista.universuljuridic.ro/supliment/european-regulation-veterinarysanitary-food-safety-area-component-european-policies-safety-foodproducts-protection-consumer-interests-2007-retrospective-2/ Accessed 5 July 2020.

27. Editorial. The double burden of malnutrition. Lancet. 2019;395:10217.

28. Sun Yat-sen University. International Symposium on One Health Research. Available: http://onehealth2.csp.escience.cn/dct/page/70007 Accessed 1 Dec 2019.

29. Yang W. 70 years of prevention and control of infectious diseases in China Guangzhou: One Health - 2nd International Symposium on One Health Research in China; 2019.

30. Lu J, Milinovich GJ, Hu W. A brief historical overview of emerging infectious disease response in China and the need for a one health approach in future responses. One Health. 2016;2:99-102. https://doi.org/10.1016/j.onehlt.2016. 07.001.

31. Chattu VK, Knight AW, Kevany S, Sehovic AB. Global health diplomacy, health and human security: the ascendancy of enlightened self-interest. J Educ Health Promot. 2019;8:107. https://doi.org/10.4103/jehp.jehp_391_18.

32. Reid M, Goosby E, Kevany S. Leveraging health diplomacy to end the tuberculosis epidemic. Lancet. 2019;7(5):Pe561-e2. https://doi.org/10.1016/ S2214-109X(19)30058-0.

33. Lebov J, Grieger $\mathrm{K}$, Womack D, et al. A framework for one health research. One Health. 2017;3:44-50. https://doi.org/10.1016/j.onehlt.2017.03.004.

34. Gebreyes W, Dupouy-Camet J, Newport M, et al. The global one health paradigm: challenges and opportunities for tackling infectious diseases at the human, animal, and environment interface in low-resource settings. PLoS Negl Trop Dis. 2014;8(11):e3257. https://doi.org/10.1371/journal.pntd. 0003257.

35. Griffith University. CEPH members' fight against COVID-19. Griffith News. Available: https://news.griffith.edu.au/2020/05/18/ceph-members-fightagainst-covid-19/ Accessed 5 July 2020

\section{Publisher's Note}

Springer Nature remains neutral with regard to jurisdictional claims in published maps and institutional affiliations.

Ready to submit your research? Choose BMC and benefit from:

- fast, convenient online submission

- thorough peer review by experienced researchers in your field

- rapid publication on acceptance

- support for research data, including large and complex data types

- gold Open Access which fosters wider collaboration and increased citations

- maximum visibility for your research: over $100 \mathrm{M}$ website views per year

At $\mathrm{BMC}$, research is always in progress.

Learn more biomedcentral.com/submissions 